\title{
NOTE ON THE ANIMAL OF THE GENUS CLEOPATRA.
}

\section{By E. A. Sмiтн, I.S.O.}

Read 11th November, 1910.

THe animal of this genus does not appear to have been observed, although the radula of $C$. bulimoides is described by 'Troschel. Mr. H. B. Preston kindly gave me specimens of $C$. ferruginea, Lea, and $C$. cingulata, Martens, which he had received from Shimbi Hills, British East Africa. These, on being placed in tepid water, revived after a period of some months in a dry condition. They appear to be very sluggish in their movements, but this may possibly be due to the unnatural conditions under which they now exist. The animals of both species are very much alike, and in general features resemble that of the genus Bithynia.
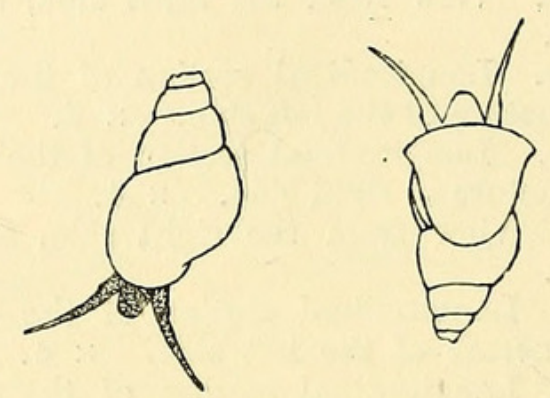

The proboscis in C. ferruginea is rather large, flattish, extensile and contractile, rather blunt at the end, and cleft longitudinally, streaked across with fine black lines. The tentacles, $7-8 \mathrm{~mm}$. in length, are very slender, and acutely pointed, transparent, but speckled with black. No neck-lappets, such as occur in Vivipara. The eyes are minute, slightly prominent, and situated on the outer side of the tentacles towards the base. Foot small, broad, widely curved in front, somewhat auriculate anteriorly at the sides, narrower and rounded behind. Above of a semi-transparent smoky appearance, mottled with yellowish specks, uniformly pale beneath.

On removing the animal from its shell the mantle is seen to be of a bright-green tint, excepting the margin, which is yellowish. The liver also is of a similar verdigris-green colour.

In $C$. cingulata the foot is a little more pointed behind, and rather more distinctly streaked with excessively fine black lines. There are yellowish mottlings between the streaks, and towards the margin it is pale and unstreaked.

As only two or three specimens have been observed it cannot be said whether these slight differences are constant or not.

On comparison with a figure of Bithynia tentaculata given by Moquin-Tandon, the foot is seen to be rather shorter and more pointedly auriculate in front, and the tentacles are more acutely tapering. 


\section{$2 \mathrm{BHL}$ Biodiversity Heritage Library}

Smith, E. A. 1911. "NOTE ON THE ANIMAL OF THE GENUS CLEOPATRA." Proceedings of the Malacological Society of London 9, 240-240.

View This Item Online: https://www.biodiversitylibrary.org/item/96830

Permalink: https://www.biodiversitylibrary.org/partpdf/203058

\section{Holding Institution}

Field Museum of Natural History Library

\section{Sponsored by}

Smithsonian

\section{Copyright \& Reuse}

Copyright Status: Public domain. The BHL considers that this work is no longer under copyright protection.

This document was created from content at the Biodiversity Heritage Library, the world's largest open access digital library for biodiversity literature and archives. Visit BHL at https://www.biodiversitylibrary.org. 